\title{
BIRDS OBSERVED IN NORTH-CENTRAL ALBERTA, SUMMER 1964
}

\author{
by Anthony J. Erskine, Canadian Wildlife Service, \\ Sackville, New Brunswick
}

In the summer of 1964 , I spent six weeks studying Buffleheads (Bucephala albeola) north of Lesser Slave Lake, in north-central Alberta. This report summarizes bird observations made by me during this period, together with a few made by my companion, Wayne P. McCrory, and by local residents. Birds of nearby areas have been reported by Baker and Walkinshaw (1946), Soper (1949), and Godfrey (1952).

The areas visited in 1964 lie close to the "Whitefish road"* from Grouard to Atikameg, and chiefly between Salt Prairie and Gift Lake (Fig. 1). A few observations were made on July 8-9 along the road northeast from Atikameg to Red Earth and Trout Mountain. These roads are largely ungravelled, and may be impassable for motor vehicles in wet weather. Lakes away from the road were reached only on foot, along logging tracks or survey lines.

Most of the area is covered with aspen (Populus tremuloides) and balsam poplar ( $P$. balsamifera) forests. A few stands of white spruce (Picea glauca), occasionally mixed with balsam fir (Abies balsamea), persist where they have escaped fire and logging. The hollows are occupied either by black spruce ( $P$. mariana) muskegs or by willow-alder (Salix-Alnus spp.) swales along brooks. Some land along the road near Salt Prairie is cultivated, and a few fields have been cleared near the settlement at Gift Lake. The terrain is gently rolling, with an average elevation of about 2200 feet. The highest and lowest elevations along the road north from Atikameg are about 2550 feet at Trout Mountain and about 1650 feet at Loon Lake.

* Local names are given in quotation marks.
We visited the area briefly on June 3,6 , and 11-12, before setting up camp at Gift Lake. Except for the periods July 2-4, July 14-16 and July 28-31, we remained there from June 15 until August 4.

\section{Annotated List}

For each species is given the number of dates upon which it was recorded and the maximum number of adults seen on one day, thus "18-3", the habitat in which it was found, and any breeding evidence obtained. Names used follow the A.O.U. Check-list (1957).

Nesting data have been recorded in detail with the Prairie Nest Records Scheme, Manitoba Museum of Man and Nature, Winnipeg.

Common Loon Gavia immer: 18-3, large and small lakes.

Red-necked Grebe Podiceps grisegena: 25-10, large and small lakes; nests or broods at 11 localities, first young June 19.

Horned Grebe Podiceps auritus: 2211, large and small lakes; nests or broods at six localities, first young July 8.

Eared Grebe Podiceps caspicus: $5-50$, scattered individuals except at Loon Lake, an area with lush emergent and submerged vegetation, where the only breeding was noted; small young July 9.

Western Grebe Aechmophorus occidentalis: $3-6$, only at Grouard, another productive marsh area; half-grown young August 3.

Pied-billed Grebe Podilymbus podiceps: 5-2, at three localities, including two fertile marshes and one muskeg pond; broods July 7 and July 18.

White Pelican Pelecanus erythrorhynchos: McCrory saw a number at Utikuma Lake August 3; local resi- 


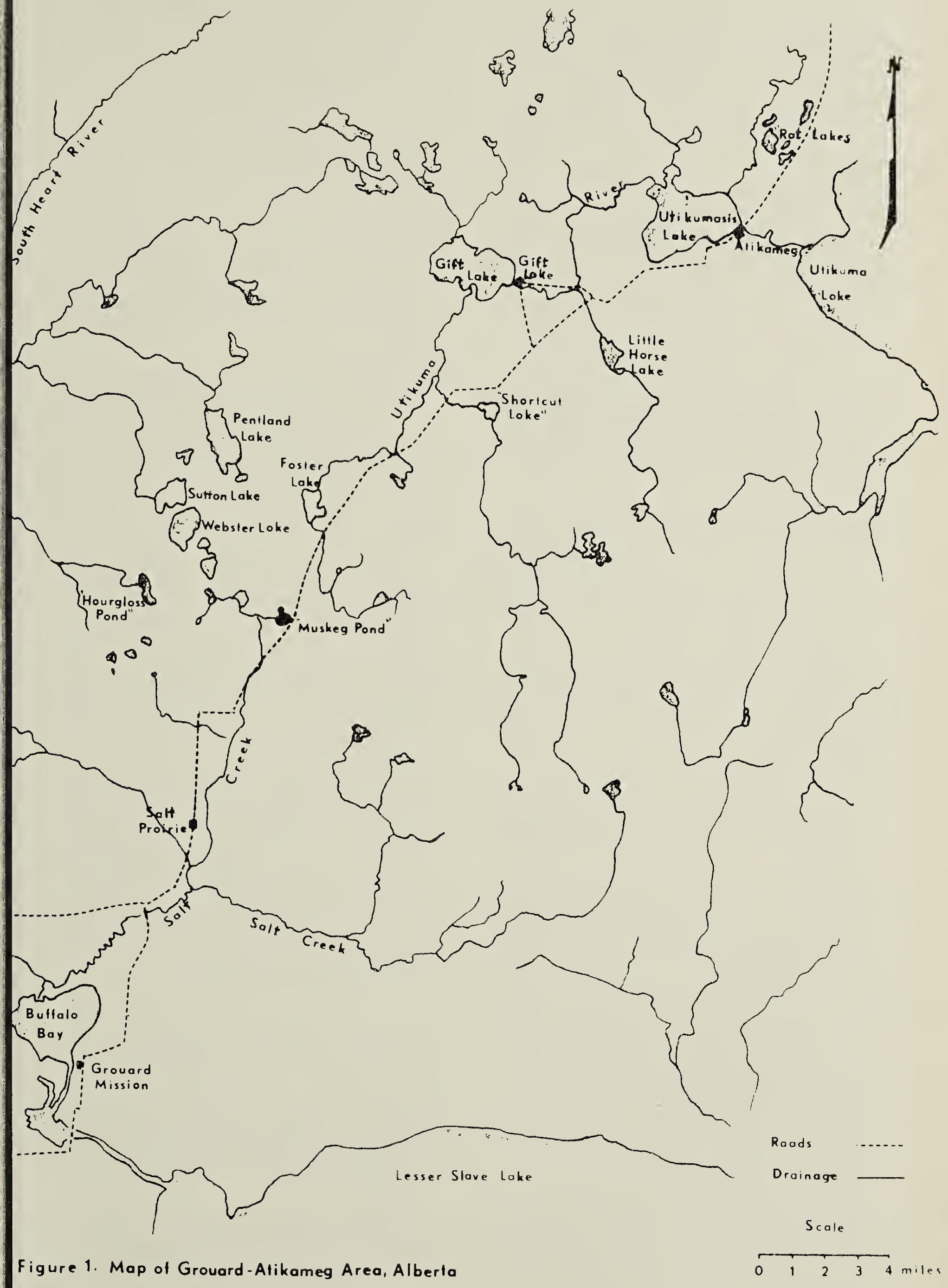

March, 1968 
dents reported pelicans to be regular at Utikuma and Pentland ("Pelican") Lakes.

Great Blue Heron Ardea herodias: one bird at Grouard July 14.

American Bittern Botaurus lentiginosus: local residents reported one near "Shortcut Creek" in early June.

Mallard Anas platyrhynchos: 27-30, scattered individuals except on a few fertile lakes; broods at 7 localities; first young June 11.

Gadwall Anas strepera: 3-10, at Loon Lake; singles elsewhere.

Pintail Anas acuta: 4-15, all at Grouard.

Green-winged Teal Anas carolinensis: 21-20, mostly on smaller lakes, and even on ponds in dense woods; nests or broods at 8 localities; first young June 25.

Blue-winged Teal Anas discors: 2210 , on most lakes, especially smaller ones, but little breeding evidence was obtained; broods at "Muskeg Pond" July 17 and 25, and at Horse Creek July 22.

American Widgeon Mareca americana: 27-18, large and small lakes; broods at 10 localities; first young June 17.

Shoveler Spatula clypeata: 8-5, scattered individuals except at a few fertile localities; nest at "Rat Lakes" June 23, brood at Grouard July 17.

Redhead Aythya americana: 9-4, only at two fertile areas; broods at "Rat Lakes" July 21 and at Grouard August 3.

Ring-necked Duck Aythya collaris: 8-20, mainly on muskeg lakes; broods at Foster Lake July 13, and at "Muskeg Pond" July 17 and 25.

Canvasback Aythya valisineria: 420 , only on fertile lakes; nest at "Rat Lakes" June 23, brood at Grouard August 3.

Lesser Scaup Aythya affinis: 33-95, also pre-moulting flock of 250 birds July 13; large and small lakes; nests or broods at 8 localities; first young July 8.
Common Goldeneye Bucephala clangula: 23-10, also pre-moulting flock of up to 100 birds on June 12 , 16, 17 and July 6; large and small lakes; one nest and broods at 8 other localities; first young June 19.

Barrow's Goldeneye Bucephala islandica: 8-6, large and small lakes; mostly pre-moulting males, including some with large flock of Common Goldeneyes.

Bufflehead Bucephala albeola: 32-22, also pre-moulting flocks of 150 birds $J$ une 12, 16, 17 and of 200 birds July 8 ; mostly on smaller lakes; nests or broods at 7 localities; first young June 18.

White-winged Scoter Melanitta deglandi: 26-20, large and small lakes; broods on Little Horse Lake July 22 and on Foster Lake July 27.

Surf Scoter Melanitta perspicillata: two males on "Shortcut Creek" July 20.

Ruddy Duck Oxyura jamaicensis: 21-15, large and small lakes, but breeding only at "Rat Lakes", a fertile area; nest June 23, broods July 21.

Goshawk Accipiter gentilis: one over pond north of Peerless Lake July 8.

Cooper's Hawk Accipiter cooperii: an immature-plumaged bird at Gift Lake June 17.

Red-tailed Hawk Buteo jamaicensis: 17-2, mostly over poplar forest; two birds by a nest 40 feet up in a balsam poplar June 18 , but nest empty when checked June 30.

Bald Eagle Haliaeetus leucocephalus: an adult at Utikumasis ("Little Whitefish") Lake near A.tikameg July 10.

Marsh Hawk Circus cyaneus: 7-1, mostly over sedge meadows by lakes.

Sparrow Hawk Falco sparverius: 258, also group of 12 including flying young July 27; mostly along edges of cleared land north of Salt Prairie, where newly-flying young were seen July 18.

Spruce Grouse Canachites canadensis: a male near "Muskeg Pond" June 18; McCrory saw a female with brood in the same area July 18. 
Ruffed Grouse Bonasa umbellus: $6-2$, all in poplar woods; at least 4 broods, the first June 22.

Sharp-tailed Grouse Pedioecetes phasianellus: an adult with 3 flying young in grassland north of Salt Prairie July 27.

Sora Porzana carolina: 14-6, in marshes by large and small lakes.

American Coot Fulica americana: 29-50, large and small lakes, but most numerous in fertile areas; broods at 5 localities; first young June 23.

Killdeer Charadrius vociferus: $25-3$, largely on cultivated land near Salt Prairie and Gift Lake; no broods seen, but behaviour of adults suggested nests or young nearby.

Common Snipe Capella gallinago: $21-3$, largely in sedge meadows beside lakes; McCrory saw an adult with one one-third-grown young near Webster ("Callahassee") Lake June 26.

Upland Plover Bartramia longicauda: one bird by the road near "Muskeg Pond" July 17.

Spotted Sandpiper Actitis macularia: 15-3, largely in cleared areas by Gift Lake.

Solitary Sandpiper Tringa solitaria: $30-7$, any wet area, even tiny pools in dense forest; a group thought to be of flying young July 21, and two small young (one caught and examineil with adults near Atikameg Auguet 4.

Lesser Yellowlegs Totanus flavipes: $29-16$, around all lakes; adult behaviour suggested breeding in area.

Pectoral Sandpiper Erolia melanotos: 2-4, presumably migrants, first July 9.

Least Sandpiper Erolia minutilla: $4-8$, presumably migrants, first July 8.

Dowitcher (probably Long-billed) Limnodromus (? scolopaceus): 311 , all adults; presumably migrants, first July 6.

Semipalmated Sandpiper Ereunetes pusillus: $2-10$, presumably migrants, first July 9.

Northern Phalarope Lobipes lobatus:
4 adults at Loon Lake July 9, presumably migrants.

Wilson's Phalarope Steganopus tricolor: 6-4, mainly around fertile lakes; behaviour of adults at "Muskeg Pond" suggested nest or brood nearby.

Franklin's Gull Larus pipixcan: 25200 , around lakes and agricultural land, but large numbers only in fertile areas; flying young at Grouard and Atikameg August 3-4.

Bonaparte's Gull Larus philadelphia: 5-32, large and small lakes; a partly feathered young north of Peerless Lake July 8, first flying young at Atikameg August 4.

Common Tern Sterna hirundo: 7-10, only at larger lakes; nesting, including one pair on a muskrat house, in marsh at Grouard, where flying young first seen August 3. Birds thought to be Forster's Terns were seen there on 4 dates, but all flying young August 3 were Common Terns.

Black Tern Chlidonias niger: $34-55$, mainly at larger lakes; flightless young at "Rat Lakes" and Little Horse Lake, from June 23; first flying young at Loon Lake July 9.

Rock Dove Columba livia: two at Salt Prairie July 20; local residents reported them nesting in barns nearby.

Mourning Dove Zenaidura macroura: 3-1, near "Rat Lakes", Salt Prairie, and Grouard.

Great Horned Owl Bubo virginianus: one bird at Gift Lake July 23.

Nighthawk Chordeiles minor: 24-3, over woods, cieared areas, and lakes.

Belted Kingfisher Megaceryle alcyon: 2--1, at Utikuma River near Gift Lake, June 16 and July 12.

Yellow-shafted Flicker Colaptes auratus: $30-8$, largely in burns and areas of drowned trees around lakes; nests in 5 localities, first flying young July 4.

Pileated Woodpecker Dryocopus pileatus: 2-2, in poplar forest.

Yellow-bellied Sapsucker Sphyrapicus varius: 24-6, in poplar forest; nests in 4 localities, first hatched young heard June 16. 
Hairy Woodpecker Dendrocopos villosus: 3-3, in poplar forest; male feeding young in nest near Pentland Lake June 22.

Downy Wood pecker Dendrocopos pubescens: $3-3$, probably two adults and ore newly flying young, west of Webster Lake June 24; in poplar forest.

Northern Three-toed Woodpecker Picoides tridactylus: a male by "Hourglass Pond" June 24, in an area of burned black spruce.

Eastern Kingbird Tyrannus tyrannus: 27-4, largely in alder-willow swales along creeks; a group believed to be of flying young was seen July 20.

Traill's Flycatcher Empidonax traillii: 16-6, largely in alder-willow swales.

Least Flycatcher Empidonax minimus: $19-7$, largely in poplar forest.

Western Wood Pewee Contopus sordidulus: $33-7$, largely in poplar forest.

Olive-sided Flycatcher Nuttallornis borealis: $13-2$, in mixed poplarwhite spruce forest.

Tree Swallow Iridoprocne bicolor: $27-15$, mostly around lakes.

Bank Swallow Riparia riparia: 2-20, at Grouard.

Barn Swallow Hirundo rustica: 2-2, around settlements; two adults feeding large young in nest in toolshed at Red Earth July 9.

Cliff Swallow Petrochelidon pyrrhonota: $9-30$, all at Grouard except at Loon Lake July 9.

Purple Martin Progne subis: 14-6, mostly around lakes; adults entering an empty flicker hole in a poplar stub near Webster Lake June 30.

Gray Jay Perisoreus canadensis: $24-$ 5 , largely in conifer forest; first flying young June 3.

Blue Jay Cyanocitta cristata: 3-1, near Salt Prairie, "Shortcut Creek", and Gift Lake.

Common Raven Corvus corax: 4-4.

Common Crow Corvus brachyrhynchos: 8-4, only twice north of cultivated land near Grouard and Salt Prairie.

Black-capped Chickadee Parus atricapillus: $18-3$, also group of 9 includ- ing newly flying young fed by adults at Gift Lake June 17; in all forests. Boreal Chickadee Parus hudsonicus: $6-2$, only in coniferous forest.

Red-breasted Nuthatch Sitta canadensis: one in mature spruce forest near Webster Lake June 26.

House Wren Troglodytes aedon: 8-3, largely in poplar forest.

Winter Wren Troglodytes troglodytes: $4-3$, all in mature spruce forest near Webster Lake.

Long-billed Marsh Wren Telmatodytes palustris: $4-7$, only in more fertile marsh areas; dummy nest found at "Rat Lakes" June 23.

Robin Turdus migratorius: $40-15$, in all areas; nest with eggs at "Shortcut Creek" June 19 was perhaps a second nesting.

Hermit Thrush Hylocichla guttata: $10-3$, largely in conifer or mixed forest.

Swainson's Thrush Hylocichla ustulata: 19-8, mostly in poplar forest; young left nest near Webster Lake June 30 .

Mountain Bluebird Sialia currucoides: a male east of Red Earth July 8.

Golden-crowned Kinglet Regulus satrapa: two in mature spruce forest near Webster Lake June 18.

Ruby-crowned Kinglet Regulus calendula: 7-3, largely in conifer or mixed forest.

Cedar Waxwing Bombycilla cedrorum: $21-8$, largely in cleared areas and along creeks.

Starling Sturnus vulgaris: $15-3$, mostly around cleared areas; large young in nest near Webster Lake June 30 .

Red-eyed Vireo Vireo olivaceus: $15-4$, largely in poplar forest.

Warbling Vireo Vireo gilvus: $12-4$, mostly around settlements.

Black-and-white Warbler Mniotilta varia: $10-2$, largely in poplar forest.

Tennessee Warbler Vermivora peregrina: $12-12$, largely around black spruce muskegs.

Yellow Warbler Dendroica petechia: 17-6, largely in alder-willow swales along creeks and lakeshores. 
Magnolia Warbler Dendroica magnolia: twa in mature spruce forest north of Salt Prairie June 11.

Cape May Warbler Dendroica tigrina: two in mature spruce forest near Webster Lake June 18.

Myrtle Warbler Dendroica coronata: 8-4, largely in conifer forest.

Black-throated Green Warbler Dendroica virens: 2-1, in mature spruce forest near Webster Lake June 22 and 24.

Bay-breasted Warbler Dendroica castanea: $2-1$, in mature spruce forest near Webster Lake June 24, 26.

Blackpoll Warbler Dendroica striata: $2-4$, in spruce forest north of Salt Prairie June 11 and at Gift Lake June 16.

Palm Warbler Dendroica palmarum: $3-2$, all in black spruce muskeg; adults carrying food June 24 .

Ovenbird Seiurus aurocapillus: $17-4$, largely in poplar forest.

Northern Waterthrush Seiurus noveboracensis: $11-9$, largely in alderwillow swales along creeks and lakeshores.

Connecticut Warbler Oporornis agilis: one north of Salt Prairie June 11.

Mourning Warbler Oporornis philadelphia: 8-5, largely in mixed or poplar forest.

Yellowthroat Geothlypis trichas: 8-4, largely in alder-willow swales along creeks.

American Redstart Setophaga ruticilla: 7-2, largely in poplar forest.

House Sparrow Passer domesticus: 12-10, around settlements.

Yellow-headed Blackbird Xanthocephalus xanthocephalus: 2-2, only in fertile marshes.

Red-winged Blackbird Agelaius phoeniceus: $40-40$, largely in sedge meadows around lakes; first flying young June 23, young from presumed second nests flying July 30 .

Baltimore Oriole Icterus galbula: a male seen and 2 heard near "Rat Lakes" June 23.

Rusty Blackbird Euphagus carolinus: $7-3$, largely in black spruce muskegs.

Brewer's Blackbird Euphagus cyano- cephalus: 5-10, largely around agricultural areas.

Common Grackle Quiscalus quiscula: 14-15, largely in alder-willow swales near water; a nest with eggs near Webster Lake June 18 may have been a second nesting.

B r ow $\mathrm{n}$ - h ea ded Cowbird Molothrus ater: 12-150, mostly large flocks of males around setlements, in June.

Western Tanager Piranga ludoviciana: one male in mature spruce forest near Webster Lake June 26.

Rose-breasted Grosbeak Pheucticus ludovicianus: 4-1, in poplar forest.

Evening Grosbeak Hesperiphona vespertina: one bird at Gift Lake June 29.

Purple Finch Carpodacus purpureus: $3-3$, all in poplar forest.

Pine Grosbeak Pinicola enucleator: a female-plumaged bird near "Hourglass Pond" June 24.

Pine Siskin Spinus pinus: $10-3$, largely in mixed or conifer forest.

American Goldfinch Spinus tristis: one heard at Gift Lake June 18.

White-winged Crossbill Loxia leucoptera: 6-10, largely in conifer forest.

Savannah Sparrow Passerculus sandwichensis: $5-3$, in agricultural land, and clearings.

Le Conte's Sparrow Passerherbulus caudacutus: $10-3$, in sedge meadows around lakes.

Sharp-tailed Sparrow Ammospiza caudacuta: 5-2, in sedge meadows around lakes.

Vesper Sparrow Pooecetes gramineus: $3-2$, all in grassland near salt Prairie and Grouard.

Slate-colored Junco Junco hyemalis: 18-6, also groups totalling 15 , including flying young July 18; largely in mixed or poplar forest.

Chipping Sparrow Spizella passerina: $15-8$, largely in poplar forest.

Clay-colored Sparrow Spizella pallida: 7 -2, all in bushy clearings along roads or around lakes.

White-throated Sparrow Zonotrichia albicollis: 26-6, largely in poplar and mixed forest.

Fox Sparrow Passerella iliaca: 11-2, 
all in alder-willow swales along Utikuma River at Gift Lake.

Lincoln's Sparrow Melospiza lincolnii: $21-6$, largely in brushy areas around lakes.

Swamp Sparrow Melospiza gèrgiana: 12 - 3, largely in alder-willow swales along creeks and lakeshores.

Song Sparrow Melospiza melodia: $18-5$, in all "edge" habitats.

\section{Discussion}

Uncritical comparison of this list with others from nearby areas may lead to unwarranted conclusions. My studies were concerned with waterfowl, so wetland habitats received disproportionately more attention than did other habitats. While only onethird (44 out of 138) of the species seen in the area can be classed as water birds or water-edge species, no less than 18 of the 30 species most frequently noted were in these categories. Birds of forest and shrub habitats were observed frequently while travelling between water areas, but grassland and cultivated areas were scarcely visited except on our trips to and from High Prairie for supplies. Studies reported by Soper (1949) and Godfrey (1952) covered much more open country than this study area. Soper's work emphasized field observations of waterfowl, so my list is likely to be more comparable with his than with that of Godfrey, who spent much time collecting and preparing museum specimens. Both Godfrey and Soper, however, visited many of the same areas, so the proportions of time they spent in various habitats may have been more similar than the nature of their work would suggest. Only the marshes at Grouard were included in all three studies.

Soper ranked the duck species in order of abundance, so it is possible to make objective comparisons between his list of these birds and mine. Leaving aside species seen only occasionally, there is close agreement except for four species, Shoveler ranking much higher on Soper's list, and Green-winged Teal, Ring-necked Duck, and Bufflehead much higher on mine. The high ranking of Bufflehead in my list is obviously due to my efforts to seek out this species. Nevertheless, all three ducks that I found relatively more common than did Soper are species characteristic of waters in forested regions. The Shoveler is more commonly found in fertile, muddy marshes is grassland regions. Godfrey's data do not permit objective ranking of duck species in order of abundance, but only two species differed markedly in status between his list and Soper's. Godfrey found Pintail one of the commonest ducks while Soper found it uncommon, and the reverse was true for Whitewinged Scoters. However, Soper found the latter chiefly in the Grande Prairie region, where Godfrey spent little time.

For birds other than ducks, Soper presented only general statements "abundant", "common", "uncommon", "rare." My numerical data indicate that the species seen in greatest numbers were the same ones which I saw most frequently, while those seen in lessier numbers appeared less often. Accordingly, one may consider those seen on 20 or more days as "common" or "abundant", those seen on 10-19 days as "fairly common", those seen on 3-9 days as "uncommon", and those seen only once or twice as "casual." There is no way of knowing whether the terms so assigned have the same meaning as when Soper used them. Most species whose status differed between Soper's list and this one are characteristic of habitats better represented in one or the other study; for example:

Species more often seen in 1944 (open country species)

Eared Grebe

Marsh Hawk

Common Crow

Long-billed Marsh Wren

Western Meadowlark

Brewer's Blackbird

Savannah Sparrow

Vesper Sparrow

Species more often seen in 1964

(woodland species)

Common Loon 
Horned Grebe

Pied-billed Grebe

Common Snipe

Solitary Sandpiper

Rusty Blackbird

Sharp-tailed Sparrow

A few species seen in 1964 have colonized this region since Soper's visit in 1944, among them Starlings (cf. Godfrey, 1952; Myres, 1958), Barn Swallows, and perhaps Mourning Doves. Other differences are less easily explained, and some may represent year-to-year changes in abundance. Such fluctuations undoubtedly occur in all birds, but they have received little attention except among game birds and threatened species. Species which may fall into this category include Great Horned Owl, Eastern Phoebe, Red-breasted Nuthatch, Solitary Vireo, Golden-crowned Kinglet, Connecticut Warbler, American Redsitart, and Wesitern Tanager, apparently more abundant in 1944, and Sparrow Hawk, Franklin's Gull, and Palm Warbler, apparently more abundant in 1964. The change was particularly striking for Franklin's Gull, which Soper identified only twice although both Godfrey and I found it abundant. Soper undoubtedly was familiar with this species, so that misidentification neied not be considered, but the difference in status seems too great to be explained solely as annual fluctuation. The unusually large numbers of Bonaparte's Gulls listed by Soper during August make one wonder if his accounts of these two species could have been transposed.

\section{Summary}

This paper lists 138 species of birds observed in 1964 during studies of waterfowl north of Lesser Slave Lake, Alberta. Comparison of relative frequency and abundance of birds showed more species characteristic of forested country and fewer birds of open country than were observed by Soper in nearby areas during waterfowl studies in 1944. Other differences are thought to be the result of year-to-year fluctuations in numbers.

\section{Addendum}

Field work elsewhere in the Peace River-Slave Lake region during the summer of 1964 produced a few records of interest, some of which support the variations in numbers suggested above. These records are given below.

Pied-billed Grebe: heard or seen near Whitelaw June 2 and 9, and near Fairview June 8 and 13 . Not previously reported in region.

Green-winged Teal: noted daily near Fairview and Whitelaw in early June. More common than suggested in previous publications.

Barrow's Goldeneye: one male and four female-like birds near Fairview June 8. Only one previous record.

Surf Scoter: one male near Fairview May 29. Presumably a delayed migr'ant.

Gyrfalcon Falco rusticolus: one north of Whitelaw, June 2, and one, possibly the same, north of Fairview the following day. Not previously reported in region. Also a delayed migrant.

Barn Swallow: at least 6 near Desmarais June 4; one near Joussard July 1. Apparently a recent arrivail.

Veery Hylocichla fuscescens: one heard in same area near Fairview May 30, June 7 and 13. Not previously reported except for old record which Godfrey (1952) rejected.

Orange-crowned Warbler Vermivora celata: one near Fairview May 31. Presumably a late migrant.

Wilson's Warbler Wilsonia pusilla: one near Fairview May 30. Not previously reported in region.

\section{LITERATURE CITED}

American Ornithologists' Union. 1957. Checklist of North American birds. Fifth Ed. $691 \mathrm{pp}$.

Baker, B. W., and L. H. Walkinshaw. 1946. Bird notes from Fawcett, Alberta. Can. FieldNat., $60: 5-10$.

Godfrey, W. E. 1952. Birds of the Lesser Slave Lake - Peace River areas, Alberta. Nat. Mus. Canada Bull. 126: 142-175.

Myres, M. T. 1958. The European Starling in British Columbia: 1947-1957. Occas. Papers B.C. Prov. Mus., $11: 1-60$.

Soper, J. D. 1949. Birds observed in the Grande Prairie - Peace River region of northwestern Alberta, Canada. Auk, $66: 233-257$. 